\title{
Ralitoline (CI-946) and CI-953 block sustained repetitive sodium action potentials in cultured mouse spinal cord neurons and displace batrachotoxinin A 20 - $\alpha$-benzoate binding in vitro
}

\author{
David M. Rock ${ }^{\mathrm{a}}$, Michael J. McLean ${ }^{\mathrm{b}, *}$, Robert L. Macdonald ${ }^{\mathrm{b}}$, \\ William A. Catterall ${ }^{c}$ and Charles P. Taylor ${ }^{\mathrm{a}}$ \\ ${ }^{a}$ Department of Pharmacology, Parke-Davis Pharmaceutical Research Division, Warner Lambert Company, Ann Arbor, MI \\ (U.S.A.), ${ }^{b}$ Department of Neurology, University of Michigan, Neuroscience Laboratory, Ann Arbor, MI (U.S.A.) and ${ }^{c}$ Department \\ of Pharmacology, University of Washington School of Medicine, Seattle, WA (U.S.A.)
}

(Received 12 December 1990; accepted 14 December 1990)

Key words: Anticonvulsant; Epilepsy; Sodium channel; Ion channel; Rat; Mouse

\begin{abstract}
Ralitoline and CI-953 are anticonvulsant compounds active in both maximal electroshock and kindling models of seizures with rodents. CI-953 $\left(\mathrm{IC}_{50}=5 \mu \mathrm{M}\right)$ and ralitoline $\left(\mathrm{IC}_{50}=2 \mu \mathrm{M}\right)$ both blocked sustained repctitive firing of sodium action potentials with effects on firing activity triggered by spontaneous excitatory postsynaptic potentials at higher concentrations. No effects on iontophoretic GABA and glutamate responses were noted. Both compounds inhibited the binding of tritiated batrachotoxinin A 20- $\alpha$-benzoate ([ $\left.\left.{ }^{3} \mathrm{H}\right] \mathrm{BTX}-\mathrm{b}\right)$ to rat brain synaptosomes with apparent $K_{\mathrm{d}}$ values of $29 \mu \mathrm{M}$ (CI-953) and $25 \mu \mathrm{M}$ (ralitoline). Our results suggest that effects on voltage-dependent sodium channels may underlie the anticonvulsant action of these compounds.
\end{abstract}

\section{INTRODUCTION}

Ralitoline (CI-946) and CI-953 (Fig. 1) are structurally related compounds with efficacy in preclinical anticonvulsant models. Both compounds potently prevent maximal electroshock-induced seizures in rats and mice when given orally and they also raise afterdischarge thresholds in kindled rats. However, neither compound pre-

\footnotetext{
* Present address: Department of Neurology, Vanderbilt University School of Medicine, 2100 Pierce Ave., Nashville, TN 37212, U.S.A.

Correspondence to: David M. Rock, Parke-Davis Research, 2800 Plymouth Rd., Ann Arbor MI, 48105, U.S.A.
}

vents clonic seizures from a variety of chemical convulsant agents in mice (bicuculline, pentylenetetrazol, strychnine, picrotoxin $)^{1,15,23}$. This profile of anticonvulsant activity is similar to those of phenytoin and carbamazepine ${ }^{7}$, standard anticonvulsant compounds used in the treatment of generalized tonic-clonic and partial seizures in man.

Both phenytoin and carbamazepine prevent
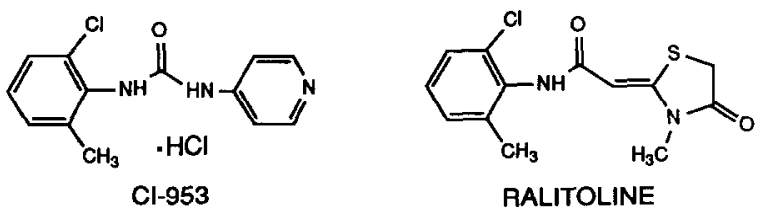

Fig. 1. Chemical structures of CI-953 and ralitoline. 
trains of rapidly repeated sodium action potentials in vitro from sustained depolarization ${ }^{11,12}$ and there is now considerable evidence that they may exert their anticonvulsant effects by acting at voltage-sensitive sodium channels involved in the initiation and propagation of action potentials in the brain $^{8,10,14,17,20-22,24,27}$. In addition, phenytoin and carbamazepine inhibit the binding of tritiated batrachotoxinin A $20-\alpha$-benzoate (BTX-b), a ligand for a specific site on voltage-dependent sodium channels that is associated with anticonvulsant and local anesthetic action ${ }^{5,26,28}$. The following studies were undertaken to determine if ralitoline and CI953 share similar effects to those of phenytoin and carbamazepine on repetitive action potentials and on BTX-b binding. Preliminary results of some of these studies were presented in abstract form ${ }^{23}$.

\section{MATERIALS AND METHODS}

\section{Electrophysiological experiments}

Cultures of fetal mouse spinal cord neurons were prepared by standard methods ${ }^{18}$. For electrophysiological experiments, cultures were placed on the heated stage of an inverted phase contrast microscope and intracellular impalements were obtained with high-resistance glass micropipettes (20-60 M $\Omega$ ) filled with either $4 \mathrm{M}$ potassium acetate or $3 \mathrm{M} \mathrm{KCl}$. Membrane potential was recorded with a conventional high-impedance bridge amplifier and displayed on a rectilinear recorder and recorded on tape. The experimental medium was Dulbecco's phosphate-buffered saline (DPBS: $\mathrm{NaCl} 137 \mathrm{mM} / \mathrm{KCl} 3 \mathrm{mM} / \mathrm{Na}_{2} \mathrm{HPO}_{4} 8$ $\mathrm{mM} / \mathrm{KH}_{2} \mathrm{PO}_{4} 1.5 \mathrm{mM} / \mathrm{MgCl}_{2} 1 \mathrm{mM}$ (spontaneous activity experiments) or substituted with $10 \mathrm{mM}$ $\mathrm{MgCl}_{2}$ (repetitive firing and iontophoretic experiments) $/ \mathrm{CaCl}_{2} 1 \mathrm{mM} / \mathrm{D}$-glucose $10 \mathrm{mM}, \mathrm{pH}$ 7.3-7.4).

Samples of CI-953 and ralitoline were obtained from Parke-Davis Research. Concentrations of ralitoline and CI-953 are expressed as the equivalent concentration of free base or acid and were dissolved into dimethyl sulfoxide (DMSO) and added to the bath to achieve the desired concentration. In each case, final concentration of DMSO was not greater than $0.1 \%$. Previous control experiments with concentrations of DMSO up to $1.0 \%$ showed no change in sustained firing, GABA or glutamate responses (data not shown). The bathing medium was static and was maintained at temperatures between $35-37^{\circ} \mathrm{C}$.

Tests were performed to determine the effect of ralitoline and CI-953 on sustained repetitive firing of sodium action potentials, spontaneous neuronal activity and postsynaptic GABA and glutamate responses. Methods are identical to those of Rock et al. ${ }^{19}$. $\mathrm{IC}_{50}$ values for repetitive firing and spontaneous activity experiments were obtained by probit analysis and significant differences from control $(P \leqslant 0.05)$ determined by a Wilcoxon ranksum test. In iontophoretic experiments, significant difference from predrug application was determined by a 2-tailed Student's $t$-test.

\section{Binding experiments}

Batrachotoxinin was obtained from Dr. John Daly, Laboratory of Bioorganic Chemistry, NIDDK, NIH. Aconitine and veratridine were from Aldrich Chemical Company. $\left[{ }^{3} \mathrm{H}\right]$ Batrachotoxinin A 20 - $\alpha$-benzoate $\left(\left[{ }^{3} \mathrm{H}\right] \mathrm{BTX}-\mathrm{b}\right)$ was from New England Nuclear Corporation. The principal $\alpha$-scorpion toxin from Leiurus quinquestriatus was purified by a modification of previously described procedures $^{3,25}$. Synaptosomes were prepared as described previously ${ }^{26}$. Stock solutions of $10 \mathrm{mM}$ ralitoline or CI-953 were made in ethanol, and diluted to give the final experimental concentrations of $1 \%$ ethanol. Control samples contained equivalent vehicle concentrations.

Specific binding of $\left[{ }^{3} \mathrm{H}\right] \mathrm{BTX}-\mathrm{b}$ was measured essentially as described previously ${ }^{6,26}$. Prior to use, an aliquot of frozen synaptosomes was thawed at $36{ }^{\circ} \mathrm{C}$ for $5 \mathrm{~min}$ and then stored on ice. Binding reactions were initiated by mixing $25 \mu \mathrm{l}$ of synaptosome suspension containing approximately $250 \mu \mathrm{g}$ of synaptosomal protein with $175 \mu \mathrm{l}$ of reaction mixture in standard binding medium $(130 \mathrm{mM}$ choline chloride/50 $\mathrm{mM}$ Hepes adjusted to $\mathrm{pH} 7.4$ with Tris base $/ 5.5 \mathrm{mM}$ glucose $/ 0.8 \mathrm{mM} \mathrm{MgSO}_{4} / 5.4$ $\mathrm{mM} \mathrm{KCl}$ ) containing $10 \mathrm{nM}\left[{ }^{3} \mathrm{H}\right] \mathrm{BTX}-\mathrm{b} / 1 \mu \mathrm{M}$ tetrodotoxin $/ 300 \mathrm{nM}$ scorpion toxin $/ 1 \mathrm{mg} / \mathrm{ml}$ bovine serum albumin and the indicated concentration of drugs. The samples were incubated at $36^{\circ} \mathrm{C}$ for 30 min. Synaptosomes and bound $\left[{ }^{3} \mathrm{H}\right] \mathrm{BTX}-\mathrm{b}$ were collected by rapid filtration on glass fiber filters 
(Whatman GF/C) and washed 3 times with $3 \mathrm{ml}$ of wash medium consisting of $163 \mathrm{mM}$ choline chloride/5 mM Hepes-Tris ( $\mathrm{pH} 7.4$ ) $/ 1.8 \mathrm{mM} \mathrm{CaCl}_{2} / 0.8$ $\mathrm{mM} \mathrm{MgSO}_{4} / 1 \mathrm{mg} / \mathrm{ml}$ bovine serum albumin. Bound $\left[{ }^{3} \mathrm{H}\right] \mathrm{BTX}-\mathrm{b}$ was determined in a liquid scintillation counter. Nonspecific binding determined in the presence of $300 \mu \mathrm{M}$ veratridine ${ }^{6}$ was subtracted from all the results presented.

Synaptosomal protein concentrations were determined according to the method of Peterson ${ }^{16}$. The results presented represent pooled data from 3 or more experiments in which each concentration of drug was examined in duplicate. Error bars represent standard error of the mean. Values for apparent $K_{\mathrm{d}}$ were estimated by probit analysis of the binding data and were corrected for small effects of the concentration of $\left[{ }^{3} \mathrm{H}\right] \mathrm{BTX}-\mathrm{b}(10 \mathrm{nM})$ and sodium channels ( $5 \mathrm{nM})$ in comparison to the $K_{\mathrm{d}}$ for BTX-b $\left(82 \mathrm{nM}^{6}\right)$.

\section{RESULTS}

In control conditions, mouse spinal cord neurons respond to increasing amplitude $450 \mathrm{msec}$ depolarizing current steps with trains of sodium action potentials that increase in frequency with larger amplitude current steps (Fig. 2, left panel). CI-953 (38 $\mu \mathrm{M}$, Fig. 2, right panel) blocked the ability of
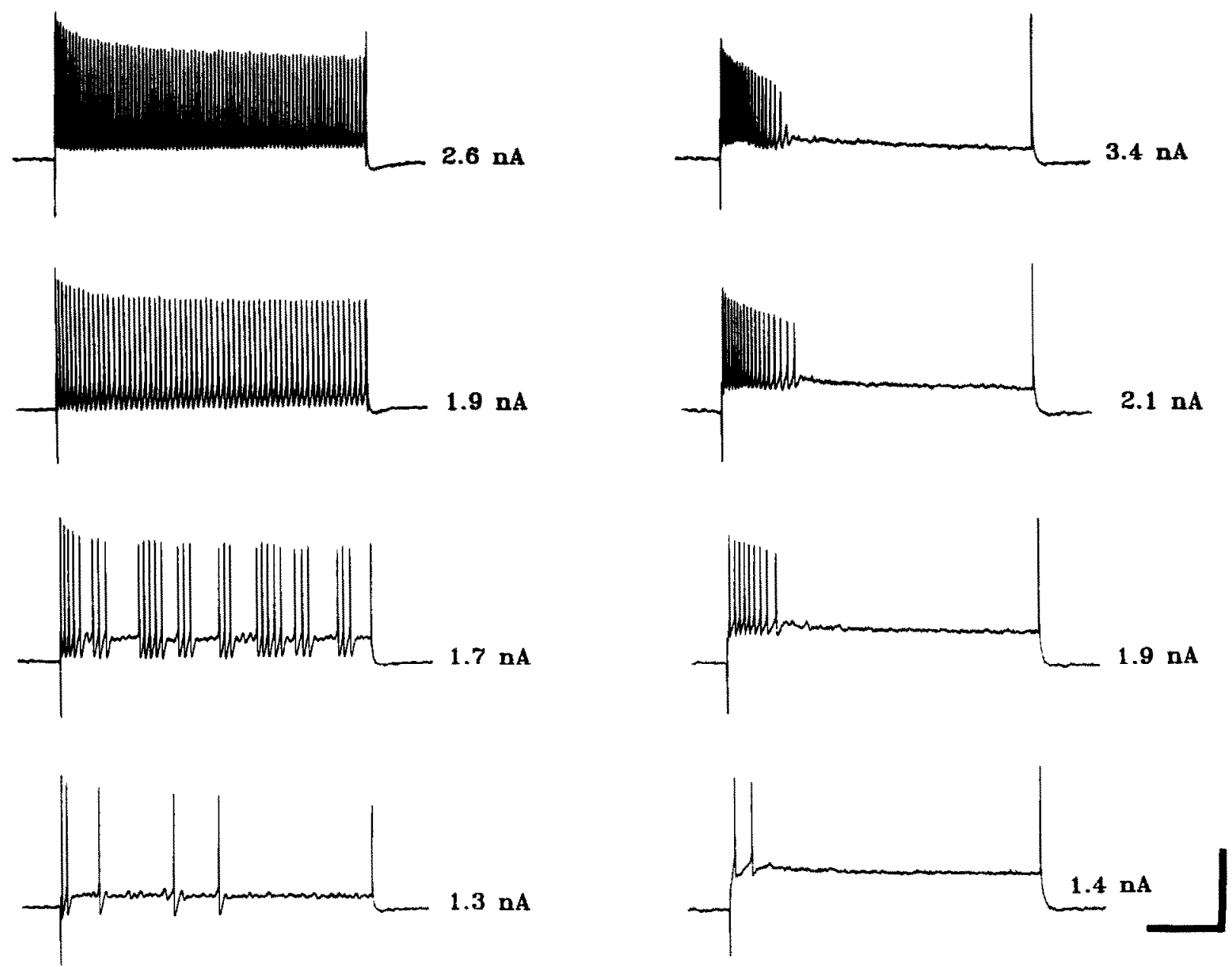

Fig. 2. CI-953 pretreatment prevents rapid sustained repetitive action potentials from depolarizing current steps in cultured spinal cord neurons. Responses in the left-hand series of traces are representative of untreated cultures, and those on the right are from another neuron representative of those treated with $38 \mu \mathrm{M} \mathrm{CI}-953$. Note that high-frequency firing was not sustained after treatment with CI-953. Calibration bars are $50 \mathrm{mV}$ and $100 \mathrm{msec}$. 
cells to fire sustained high frequency action potentials. Both CI-953 (Fig. $3 \mathrm{~A} ; \mathrm{IC}_{50}=5 \mu \mathrm{M}$ ) and ralitoline (Fig. 3B; $\mathrm{IC}_{50}=2 \mu \mathrm{M}$ ) reduced the percentage of cells that exhibited sustained repctitive firing of sodium action potentials in a concentrationdependent manner. Higher concentrations of both compounds were required to reduce spontaneous synaptically driven action potentials (Fig. 3 ).

High concentrations of CI-953 did not affect postsynaptic GABA or glutamate responses while diazepam reversibly enhanced GABA responses and phenobarbital reversibly reduced glutamate responses in agreement with published reports

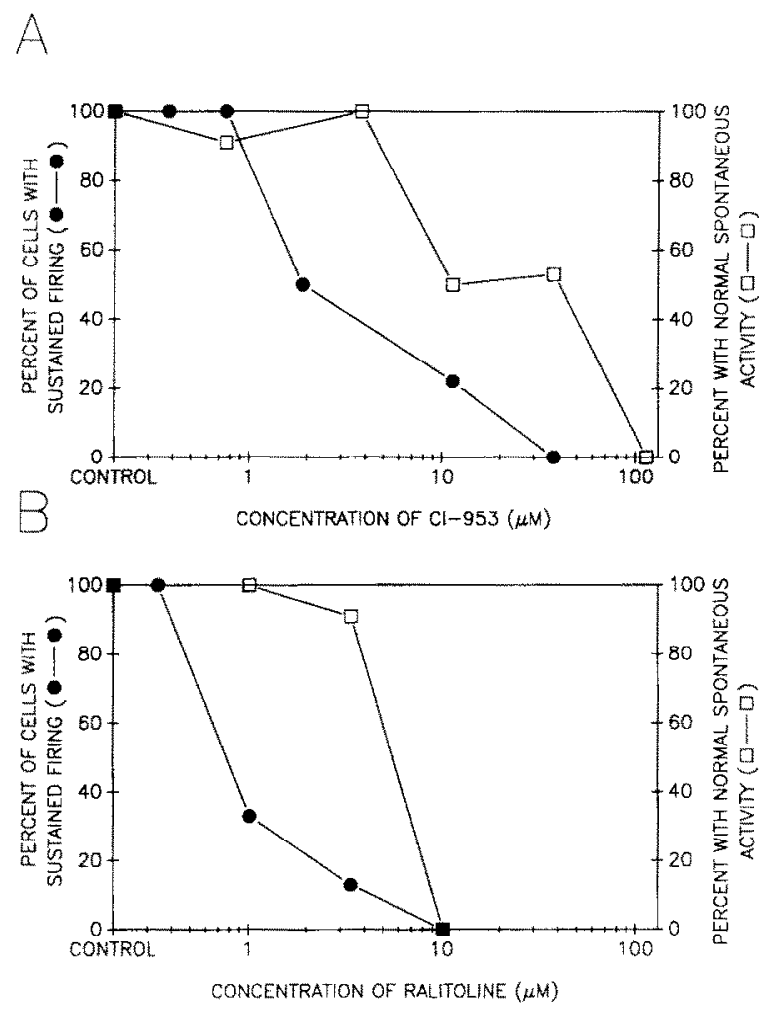

Fig. 3. Both CI-953 (A) and ralitoline (B) inhibit sustained high-frequency action potential firing in a dose-dependent manner. Closed symbols represent the percentage of cells with sustained firing at a variety of different drug concentrations. Spontaneous action potential activity (elicited by spontaneous postsynaptic potentials, not shown) was also reduced at somewhat higher concentrations (open squares). If an intracellular recording showed spontaneous activity that was markedly reduced from that seen in a large number of recordings in control medium, it was graded as reduced and the percentage of recordings with reduced activity is shown in the figure. Each data point represents recordings from 4 to 15 neurons.
TABLE I

Effect of ralitoline (C1-946) and CI-953 on iontophoretic GABA and glutamate responses

\begin{tabular}{lccc}
\hline Drug & $\begin{array}{l}\text { Test } \\
\text { concen- } \\
\text { tration }\end{array}$ & $\begin{array}{l}\text { \% Control } \\
\text { response } \\
\text { (mean } \pm \text { S.D.) }\end{array}$ & $\begin{array}{l}\text { Unbound } \\
\text { plasma } \\
\text { level }\end{array}$ \\
\hline GABA & & & \\
CI-953 & $76 \mu \mathrm{M}$ & $99 \pm 0.5 \quad(\mathrm{n}=5)$ & $4.3 \mu \mathrm{M}$ \\
$\begin{array}{l}\text { Ralitoline } \\
\text { Diazepam }\end{array}$ & $100 \mu \mathrm{M}$ & $100 \pm 2.4 \quad(\mathrm{n}=4) \quad 1.1 \mu \mathrm{M}$ \\
$\begin{array}{l}\text { Glutamate } \\
\text { CI-953 }\end{array}$ & $100 \mathrm{nM}$ & $181 \pm 21.7(\mathrm{n}=5)^{*}$ \\
Phenobarbital & $200 \mu \mathrm{M}$ & $84 \pm 3.0 \quad(\mathrm{n}=5)^{*}$ \\
\hline
\end{tabular}

${ }^{*} P \leqslant 0.05$ Student's $t$-test.

(Table I). Ralitoline did not affect postsynaptic GABA responses. No changes in membrane voltage or conductance were measured when high concentrations ( $76 \mu \mathrm{M}$ of CI-953 or $100 \mu \mathrm{M}$ of ralitoline) were applied to the cells during the iontophoretic experiments.

In radioligand binding experiments, the concentration dependences of inhibition of specific binding of $\left[{ }^{3} \mathrm{H}\right] \mathrm{BTX}-\mathrm{b}$ by $\mathrm{CI}-953$ and ralitoline are illustrated in Fig. 4. CI-953 inhibited binding with an apparent $K_{\mathrm{d}}$ value of $29 \mu \mathrm{M}$, and the data were fit by a binding curve for a single class of sites with apparent Hill coefficient of 1.08 . Similarly ralitoline had a $K_{\mathrm{d}}$ value of $25 \mu \mathrm{M}$ and Hill cocfficient of 1.16; these values are shown in Table III in comparison to published values ${ }^{26}$ for phenytoin and carbamazepine.

\section{DISCUSSION}

Concentrations of drug in plasma were calculated from pharmacokinetic data for doses $\left(\mathrm{ED}_{50}\right)$ that protect rats or mice from maximal electroshock tonic extensor seizures? ${ }^{7}$. These data are shown for CI-953, ralitoline, phenytoin and carbamazepine in Tables I and II. The values calculated for unbound drug in plasma at the $\mathrm{ED}_{50}$ dose are $4.3 \mu \mathrm{M}$ for $\mathrm{CI}-953$ and $1.1 \mu \mathrm{M}$ for ralitoline $(\mathrm{H}$. Bockbrader and A. von Hodenberg, unpublished observations). The present experiments show that ralitoline and $\mathrm{Cl}-953$ both affect high-frequency firing of sodium action potentials at these concen- 

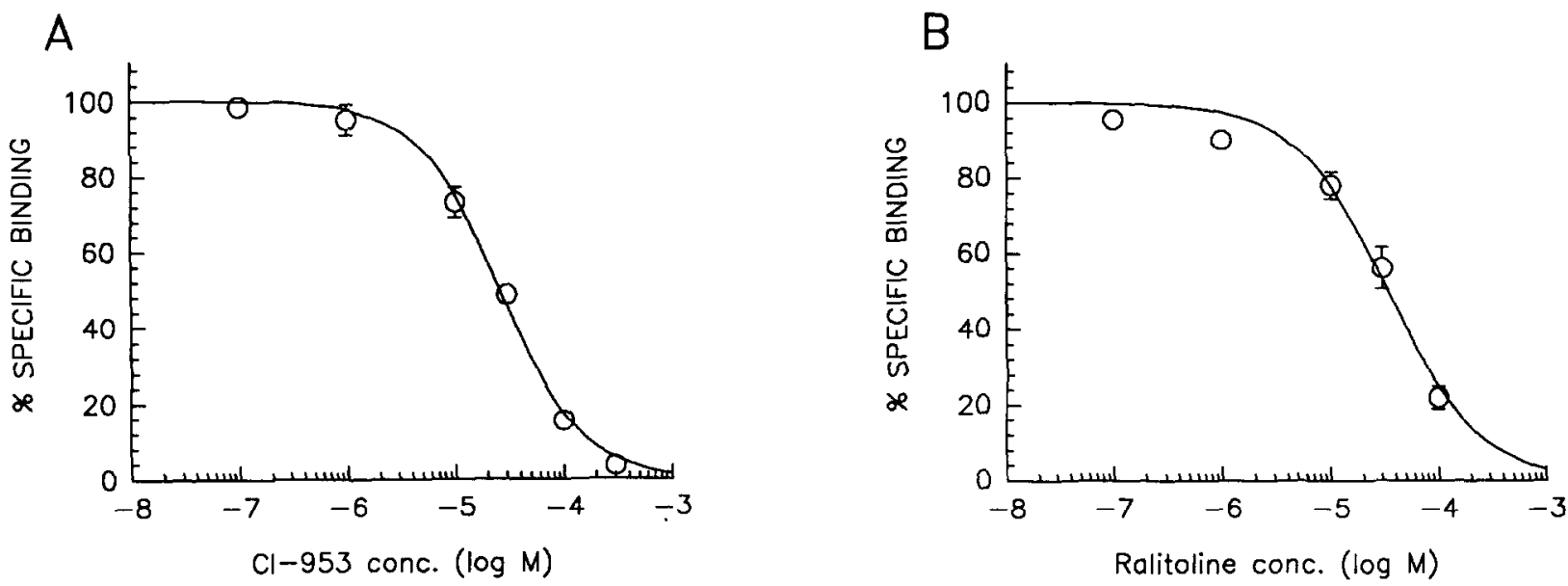

Fig. 4. Effects of CI-953 and CI-946 on BTX-b binding to sodium channels in rat brain synaptosomes. Symbols represent the specific binding as a percent of control levels, error bars represent standard errors of means. (A) CI-953 caused complete inhibition of binding at concentrations greater than $300 \mu \mathrm{M}$ with a $K_{\mathrm{d}}$ of $29 \mu \mathrm{M}$ and an apparent Hill coefficient of 1.08 . (B) Similarly, CI-946 inhibited binding with a $K_{\mathrm{d}}$ of $25 \mu \mathrm{M}$ and a Hill coefficient of 1.16 .

trations. Similar calculations for phenytoin and carbamazepine from the maximal electroshock model with rats ${ }^{9}$ agree well with clinical reports that unbound therapeutic concentrations are from 4-8 $\mu \mathrm{M}$ for phenytoin and 3-12.5 $\mu \mathrm{M}$ for carbamazepine ${ }^{2}$.

At concentrations of CI-953 or ralitoline well above the 'therapeutic levels' shown in Table I, no effects on electrophysiological responses to GABA, a major inhibitory neurotransmitter, or the excitatory neurotransmitter glutamate, were noted.

The inhibitory action of CI-953 and ralitoline on rapid trains of action potentials from sustained de-

\section{TABLE II}

Effect of ralitoline (CI-946) and CI-953 on sustained repetitive firing in vitro with comparison to unbound plasma levels attained during protection from maximal electroshock seizures in rats

\begin{tabular}{lll} 
Compound & $\begin{array}{l}I C_{50} \text { sustained } \\
\text { firing }\end{array}$ & $\begin{array}{l}\text { Unbound plasma } \\
\text { level }(\mu M)\end{array}$ \\
\hline CI-953 & 5.0 & 4.3 \\
Ralitoline & 2.0 & 1.1 \\
Phenytoin & $4-8^{\mathrm{a}}$ & $4^{\mathrm{b}}$ \\
Carbamazepine & $3-4^{\mathrm{a}}$ & $5.3^{\mathrm{b}}$ \\
\hline
\end{tabular}

${ }^{a}$ From Mclean and Mcdonald, refs. 11,12.

b From Masuda et al., ref. 9 and corrections for plasma protein binding of $87 \%$ (phenytoin) and $75 \%$ (carbamazepine). polarization of cultured spinal cord neurons is similar to results obtained with phenytoin and carbamazepine ${ }^{11,12}$ and also similar to results with valproate $^{13}$ and zonisamide ${ }^{19}$. All of the drugs that inhibit sustained firing in vitro also prevent tonic extensor seizures from maximal electroshock in rats, and all except valproate have been shown electrophysiologically and by displacement of batrachotoxinin binding to interact with voltage-sensitive sodium channels.

Both phenytoin and carbamazepine in many different voltage clamp preparations have been shown to reduce voltage-dependent inward sodium currents and to shift the voltage dependence of

\section{TABLE III}

Effect of ralitoline (CI-946) and CI-953 on BTX-b binding in rat brain synaptosomes in vitro with comparison to unbound plasma levels attained during protection from maximal electroshock seizures in rats

\begin{tabular}{llll}
\hline Compound & $\begin{array}{l}\text { Apparent } K_{d} \\
(\mu M)\end{array}$ & $\begin{array}{l}\text { Unbound } \\
\text { plasma } \\
\text { level }(\mu M)\end{array}$ & $\begin{array}{l}\text { Calculated } \\
\text { receptor } \\
\text { occupancy }\end{array}$ \\
\hline CI-953 & 29 & 4.3 & 0.14 \\
Ralitoline & 25 & 1.1 & 0.04 \\
Phenytoin & 40 & $4-8^{\mathrm{a}}$ & $0.22-0.33^{\mathrm{b}}$ \\
Carbamazepine & 131 & $3-12.5^{\mathrm{a}}$ & $0.02-0.13^{\mathrm{b}}$ \\
\hline
\end{tabular}

\footnotetext{
a From Bruni and Albright, ref. 2.

${ }^{b}$ From Willow and Catterall, ref. 26.
} 
inactivation of sodium currents to more negative voltages $^{8,10,14,20-22,24,27}$. A recent analysis of the action of phenytoin at single sodium channels has shown that phenytoin interacts with both inactivated and resting sodium channels ${ }^{17}$. It has been postulated that these changes in sodium conductance lead to the eventual blockade of sodium action potentials, especially during high frequency firing and sustained depolarizations such as those seen during seizures.

The displacement of BTX-b binding by CI-953 and ralitoline indicates that these drugs modulate binding of neurotoxins to receptor site 2 on sodium channels. This site is highly sensitive to the conformational state of the sodium channel protein and numerous neurotoxins, insecticides, local anesthetics, antiarrhythmic drugs and anticonvulsants alter neurotoxin binding by indirect allosteric interactions ${ }^{5.26}$. Analysis of the competition of binding interactions between carbamazepine and the local anesthetic lidocaine indicates a common site of interaction at the receptor ${ }^{28}$. The binding results extend the association previously made between anticonvulsant activities and allosteric inhibition of BTX-b binding ${ }^{26}$.

Table III compares the concentrations of anticonvulsants inhibiting BTX-b binding with unbound plasma concentrations achieved during prevention of seizures in rodents (Bockbrader and VonHodenberg, unpublished observations) or therapeutic concentrations in clinical studies with phenytoin and carbamazepine. Phenytoin, carbamazepine and CI-953 each occupy between $13 \%$ and $33 \%$ of sodium channel sites at therapeutic concentrations. Ralitoline occupied approximateJy $4 \%$ of sodium channel sites. Other anticonvul-

\section{REFERENCES}

1 Bartoszyk, G.D., Dooley, D.J., Fritschi, E. and Satzinger, G., Ralitoline: A Thiazolidinone. In: B.S. Meldrum and R.J. Porter (Eds.), New Anticonvulsant Drugs, Libbey, London, 1986, pp. 309-311.

2 Bruni, J. and Albright, P.S., The clinical pharmacology of antiepileptic drugs, Clin. Neuropharmacol., 7 (1984) 1-34.

3 Catterall, W.A., Purification of a toxic protein from scorpion venom which activates the action potential $\mathrm{Na}^{+}$ionophore, J. Biol. Chem., 251 (1976) 5528-5536. sants (valproate, phenobarbital, diazepam) had little effect on BTX-b binding at therapeutic concentrations $^{26}$. The actual occupancy of these lipophilic drugs may be higher, since they may significantly partition into brain membranes and increase concentration at sodium channels. Moreover, since inhibition of sodium channels is strongly frequency and voltage dependent ${ }^{10,17,21,27}$, the effective $K_{d}$ in an epileptic focus may be more potent than in binding experiments with synaptosomes. It will be interesting to examine the frequency and voltage dependence of CI-953 and ralitoline for inhibition of voltage-clamped sodium currents.

In summary, our results show inhibition of sustained repetitive action potentials from neuronal membrane depolarization and also inhibition of BTX-b binding from rat synaptosomal membranes by both CI-953 and ralitoline at concentrations that are relevant for the anticonvulsant actions of these compounds in animals. We conclude that the anticonvulsant mechanism of these two compounds is likely to be very similar to that of phenytoin and carbamazepine, and may involve modulation of neuronal voltage-sensitive sodium channels.

\section{ACKNOWLEDGEMENTS}

The authors wish to thank Mr. Carl Baker for excellent technical assistance in the receptor binding studies and Ms. Nancy Fox and Mr. Greg Campbell for technical assistance with cell cultures. Portions of the work were supported by NIH Research Grant NS15751 to W.A.C.

4 Catterall, W.A., Neurotoxins that act on voltage-sensitive channels in excitable membranes, Annu. Rev. Pharmacol. Toxicol., 20 (1980) 15-43.

5 Catterall, W.A., Common modes of drug action on $\mathrm{Na}^{+}$ channels: local anesthetics, antiarrhythmics and anticonvulsants, Trends Pharmacol. Sci., 8 (1987) 57-65.

6 Catterall, W.A., Morrow, C.S., Daily, J.W. and Brown, G.B., Binding of batrachotoxinin A 20 - $\alpha$-benzoate to a receptor site associated with sodium channels in synaptic nerve ending particles, J. Biol. Chem., 256 (1981) 8922-8927. 
7 Krall, R.L., Penry, J.K., White, B.G., Kupferberg, H.J. and Swinyard, E.A., Antiepileptic drug development, II. Anticonvulsant drug screening, Epilepsia, 19 (1978) 409-428.

8 Lipicky, R.J., Gilbert, D.L. and Stillman, I.M., Diphenylhydantoin inhibition of sodium conductance in squid giant axon, Proc. Natl. Acad. Sci. USA, 69 (1972) 1758-1760.

9 Masuda, Y., Utsui, Y., Siraishi, Y., Karasawa, T., Yoshida, K. and Shimizu, M., Relationships between plasma concentrations of diphenylhydantoin, phenobarbital, carbamazepine, and sulfamoylmethyl-1,2-benzisoxazole (AD810), a new anticonvulsant agent, and their anticonvulsant or neurotoxic effects in experimental animals, Epilepsia, 20 (1979) 623-633.

10 Matsuki, N., Quandt, F.N., Ten Eick, R.E. and Yeh, J.Z., Characterization of the block of sodium channels by phenytoin in mouse neuroblastoma cells, J. Pharmacol. Exp. Ther., 228 (1984) 523-530.

11 McLean, M.J. and Macdonald, R.L., Multiple actions of phenytoin on mouse spinal cord ncurons in cell culture, $J$. Pharmacol. Exp. Ther., 227 (1983) 779-789.

12 McLean, M.J. and Mcdonald, R.L., Carbamazepine and 10,11-epoxycarbamazepine produce use- and voltage-dependent limitation of rapidly firing action potentials of mouse central neurons in cell culture, J. Pharmacol. Exp. Ther., 238 (1986) 727-738.

13 McLean, M.J. and Macdonald, R.L., Sodium valproate, but not ethosuximide, produces use- and voltage-dependent limitation of high frequency repetitive firing action potentials of mouse central neurons in cell culture, J. Pharmacol. Exp. Ther., 237 (1986) 1001-1011.

14 Neuman, R.S. and Frank, G.B., Effects of diphenylhydantoin and phenobarbital on voltage-clamped myelinated nerve, Can. J. Physiol. Pharmacol., 55 (1977) 42-47.

15 Pavia, M.R., Lobbestael, S.J., Taylor, C.P., Hershenson, F.M. and Miskell, D.L., N-phenyl-N'-pyridinylureas as anticonvulsant agents, J. Med. Chem., 33 (1990) 854-861.

16 Peterson, G.L., A simplification of the protein assay method of Lowry et al. which is more generally applicable, Anal. Biochem., 83 (1977) 346-356.

17 Quandt, F.N., Modification of slow inactivation of single sodium channels by phenytoin in neuroblastoma cells, $\mathrm{Mol}$. Pharmacol., 34 (1988) 557-565.

18 Ransom, B.R., Neale, E., Henkart, M., Bullock, P.N. and
Nelson, P.G., Mouse spinal cord neurons in culture, I Morphology and intrinsic neuronal electrophysiological properties, J. Neurophysiol., 40 (1977) 1132-1150.

19 Rock, D.M., Macdonald, R.L. and Taylor, C.P., Blockade of sustained repetitive action potentials in cultured spinal cord neurons by zonisamide (AD 810, CI 912), a novel anticonvulsant, Epilepsy Res., 3 (1989) 138-143.

20 Schauf, C.L., Davis, F.A. and Marder, J., Effects of carbamazepine on the ionic conductances of Myxicola giant axons, J. Pharmacol. Exp. Ther., 189 (1974) 538-543.

21 Schwarz, J.R. and Grigat, G., Phenytoin and carbamazepine: potential- and frequency-dependent block of $\mathrm{Na}$ currents in mammalian myelinated nerve fibers, Epilepsia, 30 (1989) 286-294.

22 Schwarz, J.R. and Vogel, W., Diphenylhydantoin: excitability reducing action in single myelinated nerve fibres, Eur. J. Pharmacol., 44 (1977) 241-249.

23 Taylor, C.P., Rock, D.M., McLean, M.J. and Macdonald, R.L., In vivo anticonvulsant activity and in vitro blockade of repetitive action potentials by two putative anticonvulsants, ralitoline (CI-946) and CI-953, Soc. Neurosci. Abstr., 13 (1987) 94.

24 Wakamori, M., Kaneda, M., Oyama, Y. and Akiaka, N., Effects of chlordiazepoxide, chlorpromazine, diazepam, diphenylhydantoin, flunitrazepam and haloperidol on the voltage-dependent sodium current of isolated mammalian brain neurons, Brain Res., 494 (1989) 374-378.

25 Wang, G.K. and Strichartz, G.R., Purification and physiological characterization of neurotoxins from venoms of the scorpions Centruroides sculpturatus and Leiurus quinquestriatus, Mol. Pharmacol., 23 (1985) 519-533.

26 Willow, M. and Catterall, W.A., Inhibition of binding of $\left[{ }^{3} \mathrm{H}\right]$ batrachotoxinin A 20 - $\alpha$-benzoate to sodium channels by the anticonvulsant drugs diphenylhydantoin and carbamazepine, Mol. Pharmacol., 22 (1982) 627-635.

27 Willow, M., Gonoi, T. and Catterall, W.A., Voltage clamp analysis of the inhibitory actions of diphenylhydantoin and carbamazepine on voltage-sensitive sodium channels in neuroblastoma cells, Mol. Pharmacol., 27 (1985) 549-558.

28 Zimanyi, I., Weiss, S.R.B., Lajtha, A., Post, R.M. and Reith, M.E.A., Evidence for a common site of action of lidocaine and carbamazepine in voltage-dependent sodium channels, Eur. J. Pharmacol., 167 (1989) 419-422. 